FACTA UNIVERSITATIS

Series: Visual Arts and Music Vol. 4, N 1, 2018, pp. 25 - 33

https://doi.org/10.22190/FUVAM1801025B

Original scientific paper

\title{
KONAK IN GORNJA CRNUCA: THE COURT OF PRINCE MILOS OBRENOVIC
}

\author{
UDC 728.81(497.11 GORNJA CRNUCA)
}

\section{Tijana Borić}

\author{
University of Niš, Faculty of Arts, Serbia
}

\begin{abstract}
The process of founding and shaping a capital proved to be one of the key issues within the representative culture in any era. This was of particular importance when it came to the $19^{\text {th }}$ century societies in the Balkans due to the emergence of national consciousness and the creation of nation-states on what had been Ottoman territory for quite a long time. Despite the lack of independence and extreme political circumstances, the Serbian community was aware of contemporary European phenomena in creating and disseminating the ruler's image as an important part of enhancing the sense of national identity. The heart of Serbia under the reign of Milos Obrenovic was a princely court in Gornja Crnuca that, in spite of its structural simplicity, was an unmistakable expression of the highest state authorities.
\end{abstract}

Key words: Gornja Crnuca, Prince Milos Obrenovic, princely court, dynastic topos, ruler, capital

\section{INTRODUCTION}

After the failure of the First Serbian Uprising led by Karadjordje in 1813, another peasant revolutionary, Milos Obrenovic, slowly but surely, took over the leadership of Serbian struggle for independence and emancipation from the Ottoman Empire. The period between the collapse of the initial phase of the Serbian Revolution in 1813 and the consolidation of Milos Obrenovic as the hereditary prince of Serbia in 1817 that would set the roots for the eventual sovereignty and independence of the Serbian state was a phase of overwhelming uncertainty and instability. In this period, therefore, one could not expect a continuation of those intense architectural activities that had been so evident in revolutionary Serbia by the beginning of the $19^{\text {th }}$ century (Vujovic $1986,91-100$ ). Former Karadjordje's fellow insurgent and Duke of Rujan and Rudnik (Fig. 1) in the area, proved to be a patient, yet determined diplomat, so the Turks recognized Milos'

Received September, 2018 / Accepted October 2018

Corresponding author: Tijana Borić

University of Niš, Faculty of Arts, Serbia

E-mail: tijanaboric@hotmail.com 
position as the Serbian leader granting him the status of a knez (prince) of three central Serbian districts: Rudnik, Pozega, and Kragujevac (Milićević 1876, 325).

One of the crucial issues of the newly elected Serbian leader was the choice of a proper place to set up his capital and court. Here, we should highlight that Milos chose diplomacy as a means to conduct extended negotiations with the Turks, therefore to act from the position of a politically active member of the Ottoman Empire. This implied that he appropriated and imitated life practices, behavioral models and communication patterns of the Ottoman elite members which had a significant effect on the Serbian ruler's identity, both, in terms of the appearance, and the structure of his princely court. By the same time Europe witnessed a boom of the absolutist imperial programs wherein the Christomimetic character of the emperor and the concept of his unrestricted power reached its climax (Kuljić 2009, 260-265). These ideas and phenomena were transferred and appropriated by Serbia regardless of the extreme political circumstances. The struggle for independence was accompanied by the development of the representative ruler's image, the one who played a key role in shaping the court. This image was shaped by using elaborated mechanisms of glorification of rulers supported by many phenomena of visual culture that had been developed Europe-wide during the $19^{\text {th }}$-century framework (Borozan 2006, 66-95). Members of the Serbian political elite were well aware of them.

\section{FOUNDING THE CAPITAL IN GORNJA CRNUCA}

Aiming at proving his newly gained status, Milos Obrenovic founded his court and the capital of Serbia in a little village named Gornja Crnuca, on the slopes of Rudnik Mountain dominating the Sumadija region of the central part of Serbia. Gornja Crnuca was the capital of what Serbia used to be from 1814 until 1818. By that time it had been carefully chosen as an ideal center for the accomplishment of the project of national independence and the affirmation of Prince Milos as a national ruler. Having located his residential estate at a safe distance from the crowded roads, he secured his position of national leadership. Associated with the Ottoman authorities, even helping them in the suppression of a new revolt launched by Hadzi Prodan Gligorijevic in 1814, Milos Obrenovic eliminated all of his possible political rivals, thus ensuring his supreme authority. Moreover, he offered, there in Gornja Crnuca, safe refuge for all loyal leaders. The core of the rebellion had now been transferred from Topola to Gornja Crnuca. Consequently, having gathered his acknowledged followers he could begin his own uprising in 1815. After a series of quick military losses, the Ottomans granted a large degree of autonomy to Serbia and recognized undisputed rule to Prince Milos.

Consciously, Milos granted his estate structural simplicity and it was hardly different from other neighboring rural settlements. Nevertheless, the household with fertile fields, cultivated orchards, vineyards, active mills, and full barns reflected the material progress of a successful landlord. Alike Karadjordje's first seat in Topola (Borić 2014, 16-18), Milos' capital should have left the impression of a prosperous community led by a highly capable paterfamilias and a respectable head of the undisputed authority. The neatly maintained and carefully controlled household implied an undisputable allusion to successful management, independence and controlled security of everyday life. A household surrounded by the pastoral landscape and idealized nature was a manifesto of the idea of freedom, an Arcadian refuge from the existing reality of daily turmoil (Fig. 2). 


\section{MORPHOLOGY OF KONAK IN GORNJA CRNUCA}

Milos Obrenovic's court was located within an isolated valley surrounded by thick forests near the river Gruza. The residence, a log house, and its immediate surroundings were shaped according to the local traditional building concept characteristic for countryside dwellings in the Takovo region (Vujović 1986, 127; Deroko 1940). The reduced range of colors of the natural materials used, further stresses the desired harmonious impression of the primordial power and the host's safe haven. The rustic log cabin has a characteristic high steep roof with shingles providing it with a protective appearance. It has a typical wooden chimney with a cap. The semi-story of the ground area is pressed against a slant (Fig. 3). Made out of the stone, it was used as a storage space for bulky goods and wine.

The upper part of Milos' konak was made out of wooden planks. It consisted of two usual parts - 'house' and 'room' (Kadijević 2006, 250). The so-called 'house' is a traditional space with a mandatory open fireplace that constantly burns, representing the real and symbolic center of the home and the gravitating focal point of all the household members. Here is the 'house' that usually has two oppositely placed entrances. The 'room' had an earthenware heater made out of clay pots, and this area was used for sleeping (Kojić 1958, 56; Milošević 2006, 158-159).

The building has a prominently covered porch that was used for family gatherings and for daily household chores and, during the summer season, it would be turned into a place for dining and sleeping. This functional and constructive expressiveness makes the porch a striking element of the façade.

In addition to the main building, there were several neat looking auxiliary buildings such as dairies, barns, wells, and horse stables. The entire complex was surrounded by cultivated orchards and fertile fields leaving an overall impression of well-being in those times. Felix Kanitz, a well known Austro-Hungarian ethnographer and anthropologist left us a precious, though later description of this place (Kanic 1985, 333). Touched by the modesty of this prominent prince's seat, he couldn't help but notice that despite the simplicity and reduced form, it carries the direct and unmistakable message that it was the seat of the local ruler within the real circumstances of a particular historical moment.

\section{SPATIAL FEATURES AND USE OF THE KONAK IN GORNJA CRNUCA}

The space inside the konak was used mostly during the winter season, and the use of this area was defined by well-established, deep-rooted and unspoken rules. The host used the place directly opposite the fireplace exclusively. His chair was singled out by its size and the position at the head of the table. Other male members of the community would have occupied positions around the table in relation to their importance within the community.

According to the mental geography of a rural community, the immediate environment of a house, such as the garden and the yard, represented a place of collective privacy and in a certain way an extended space of the house (Timotijević 2006, 165-244). A little bit further from the konak in Crnuca there was an apple tree "under which the audacious prince often met with his confidant supporters in 1814" (Kanic 1985, 333). The tree symbolically and functionally could be understood as space which primarily belongs to the leader (Timotijević 2006, 195). In 1815, on Palm Sunday, Prince Milos Obrenovic 
ritually raised a banner in front of the konak, handing it to his closest staff member of the court of the Obrenovics, Sima Milosavljevic Pastrmac, and then addressed the gathered people announcing the Second Serbian Uprising (Kunibert 1901, 72; Marković 1938, 13). Since then it was Crnuca that was marked as the place where the uprising was initiated although, very soon, Takovo would be recognized as a stronger topos of patriotic religion and a very influential dynastic propaganda tool. That is why via conscious interventions Crnuca would be erased from the collective consciousness of the nation as a rising center (see: Timotijević 2012).

In Crnuca, we do not find the characteristic courtly awareness and understanding of the public and private sphere. Nonetheless, there had already been established a circle of chosen privileged individuals enjoying the royal grace who were granted direct access to the ruler within his residence. Also, there were a number of servants in Crnuca who served the prince and his family on a daily basis. Milan Dj. Milicevic, a Serbian biographer left an account about daily routine at konak in Crnuca in his Memoirs (Milićević 1888, 807):

"Milos' house, at that time, was very humble. Prince Milow and Princess Ljubica lived there with their children. Speaking about courtiers and servants there were only Dimitrije Djordjevic, a scribe, Lazar Arandjelovic (nicknamed Indja), a stable master, then Vule Glirgorijevic, a coffee chef, Arsa Andrejevic, a chef, and Petar Lazarevic whose duty was to light up the long-stemmed chibouk pipes and serve coffee. On top of all of them was Vuk Perisic, a boss who supervised everyone.

Petar once told me that in the room, on the floor, the mattress would be spread in the evening for Prince Milos and Princess Ljubica to sleep on. Under their feet Vule and Pera Cukic would lie down. In the morning, when the Prince was supposed to get up, he would shout and push Vule with his feet to wake him and make him get up. The Princess would do the same to Pera. Vule would then go to light up the fire and Pera would bring a hand basin and a pitcher of water offering the Prince to wash his face."

From a humble record and a few other sources, we learn that Toma Vucic-Perisic who would become the most powerful Serbian politician in the middle of the $19^{\text {th }}$ century started his political career at the court in Gornja Crnuca as the head of the prince's court and the court economy (Marković 1938, 15). Beside him, the Prince's man of trust was the above mentioned Dimitrije Djordjevic who held a position of the interpreter, scribe, and treasurer (Milićević 1876, 197).

The court in Crnuca was attended by many individuals that would eventually become members of Milos' complex and extensive governing and administrative apparatus. There often came the highly educated Jovan Miokovic, the first accountant who founded Milos' financial administration (Marković 1938, 14). Another frequent guest at the court in Crnuca was father Melentije Pavlovic, a prior of the renewed monastery of Vracevsnica who was the cultural and political center of the entire region (Milićević 1876, 273). He would eventually become the first Metropolitan in restored Serbia. We have already mentioned Sima Milosavljevic Pastrmac who represented some kind of court advisor; in addition to him, Milos regularly hosted his personal secretaries Sima Urosevic, Nikola Nikolajevic and Avram Petronijevic (Milićević 1876, 197). 


\section{PRINCESS LJUBICA’S ROLE IN GORNJA CRNUCA}

The political ambition of Prince Milos to reach the status of hereditary prince determined the life and behavioral patterns of all the members of the ruling family. Using his paternal authority Prince Milos fully controlled all aspects of family life and the distribution of financial resources. An important figure at Milos' court, who, to a lesser degree, took over the governmental duties in his physical absence becoming his representative, was Milos' wife Princess Ljubica (Fig. 4). Traditionally, the role of wife implied the home and family sphere, and that was primarily reflected within the framework of a proper housekeeping and appropriate children upbringing. Nevertheless, Princess Ljubica expressed an increased interest in public affairs and social engagement, and so, among other duties, that in the Prince's absence, she would take over. She was acting as official treasurer of the princely court in Crnuca (Marković 1938, 14-15). Otto Dubislav von Pirch who happened to take a trip to the Balkans in 1829 recorded how important was the role of Princess Ljubica when it comes to social activities and state affairs (Pirh 1899, 64):

“... Serbs appreciate their Princess and in case of her husband's accidental death, it is held that the public opinion would hand over the power to Mrs. Ljubica ..."

Princess Ljubica stood out from the usual patterns and conventional gender roles of that time. The war years influenced her skillful gun handling and horse riding that was proven by her active partaking at the battles of Ljubic and of Nikolje (Milićević 1876, 332). Apparently, the Prince and the Princess were not only an emotional couple. More than that, they were complementary partners in state affairs. Generally speaking, according to the conventional patriarchal norms, the concept of honor was deeply incorporated into the ruler's identity. As the issue of male honor was inseparable from a woman the moral image of the wife tended to be extremely important, as well as an influential social component. Furthermore, the ruling couple was considered a pillar of society and a national exempla virtutis. Therefore, Prince Milos and Princess Ljubica needed to reflect via their public appearance and deeds all those desirable standards of the patriarchal family hierarchy that understood male domination and female obedience (Vuletić 2006, 113-119; See also: Stolić 2006, 89-111). In this regard, we should read a record that in the presence of guests, the Princess acted as a guardian of the tradition serving them lunch and remained standing by the table (Pirh 1899, 66).

On the other hand, the konak in Crnuca was marked by an almost legendary story about the murder of the local beauty Petrija, whom besides the Turkish lady named Jelenka, was a long-time lady-in-waiting of Princess Ljubica and the Prince's mistress. The well-known Milos' affection for beautiful women and his "loose understandings in fulfilling his marital duties to his wife" led to an unpleasant and fatal incident when pregnant Princess Ljubica accidentally showed up in the konak in Crnuca and killed Petrija after catching her in flagrante delicto with her husband in their bed (Gavrilović 1909, 714-719). 


\section{CONCLUSION}

The fact that the court complex in Crnuca was a household that was quickly set and that could be easily left if needed reveals that Prince Milos had a plan to raise and expand his court in regards to his rising role and growing rank within the society. At the beginning of his reign, until Serbia was proclaimed a Principality, Prince Milos focused to homogenize the state and to centralize his power. After the Second Uprising of 1815, the Prince traveled frequently, yet he always returned to his residence in Crnuca. Thanks to the achievements and merits gained in the Second Serbian Uprising, Prince Milos confirmed himself as the supreme national leader. The complex in Crnuca helped the constitution of this ideological image within the framework of the project of national liberation. Having built his residence that did not that obviously stood out from the common houses of the people at that time Prince Milos used it to identify himself as a national ruler originating from his own people. This concept of the common people origin of Prince Milos will be inserted as the basic concept of the dynastic program of the Obrenovic Dynasty (see: Borozan 2006).

Ever since the Uprising of 1815 until the adoption of the Constitution of the Principality of Serbia known as the Sretenje Constitution in 1835, people addressed Milos Obrenovic as my Lord with the addition of 'serene' ("My Serene, the Most Merciful Lord"), and he was signed for a long period as the Supreme Prince. This reveals much about his evident aspirations and the desired form of government he strove for in this period (Ljušić 1986, 119-120). It was at the court in Gornja Crnuca where the first rebellion assembly was held on December 19, 1815, when the budget of Serbia in the uprising was adopted, the members of the council were elected, and a decision was made on the obligation to keep tax records (Marković 1938, 14). It is worth mentioning that on that occasion the decision was made to officially proclaim Prince Milos the "supreme prince and ruler of the Serbian people", thus paving the way for the subsequent resolution of the Assembly held in Belgrade on November 6,1817, where Milos' family was granted the title of hereditary prince (Ibid.). 


\section{Illustrations}

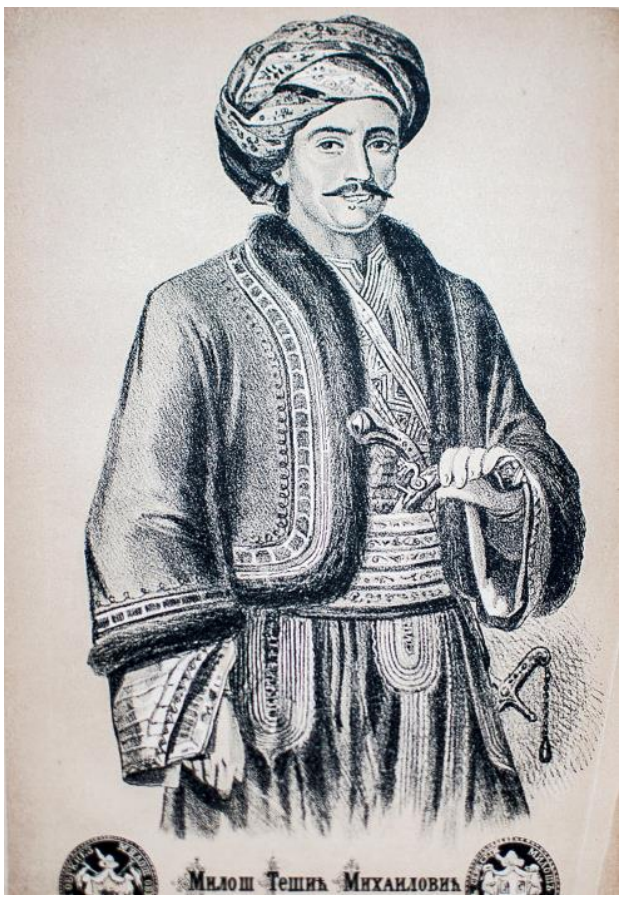

Fig. 1 Prince Milos Obrenovic, a lithograph of an unknown author published in the book: K. N. Nenadovic Život i dela velikog Đorđa Petrovića Kara-đorđa I, Vienna (1883)

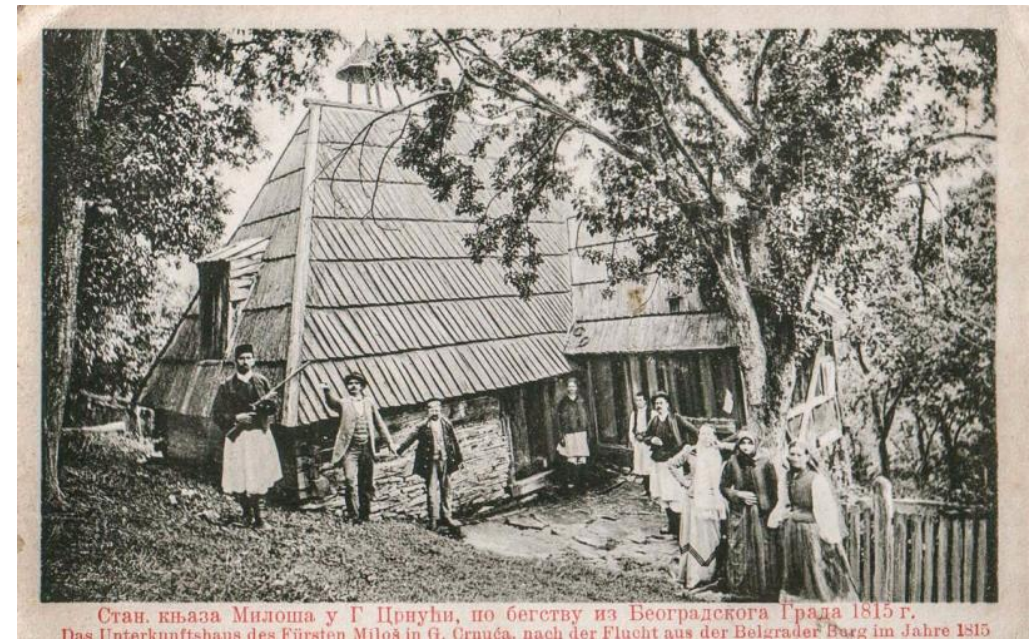

Fig. 2 Konak of Prince Milos in Gornja Crnuca, postcard published by Radojica Joksic, from the collection Cacak in Old Postcards of the City Library in Cacak available via digital collections of the National Library of Serbia 


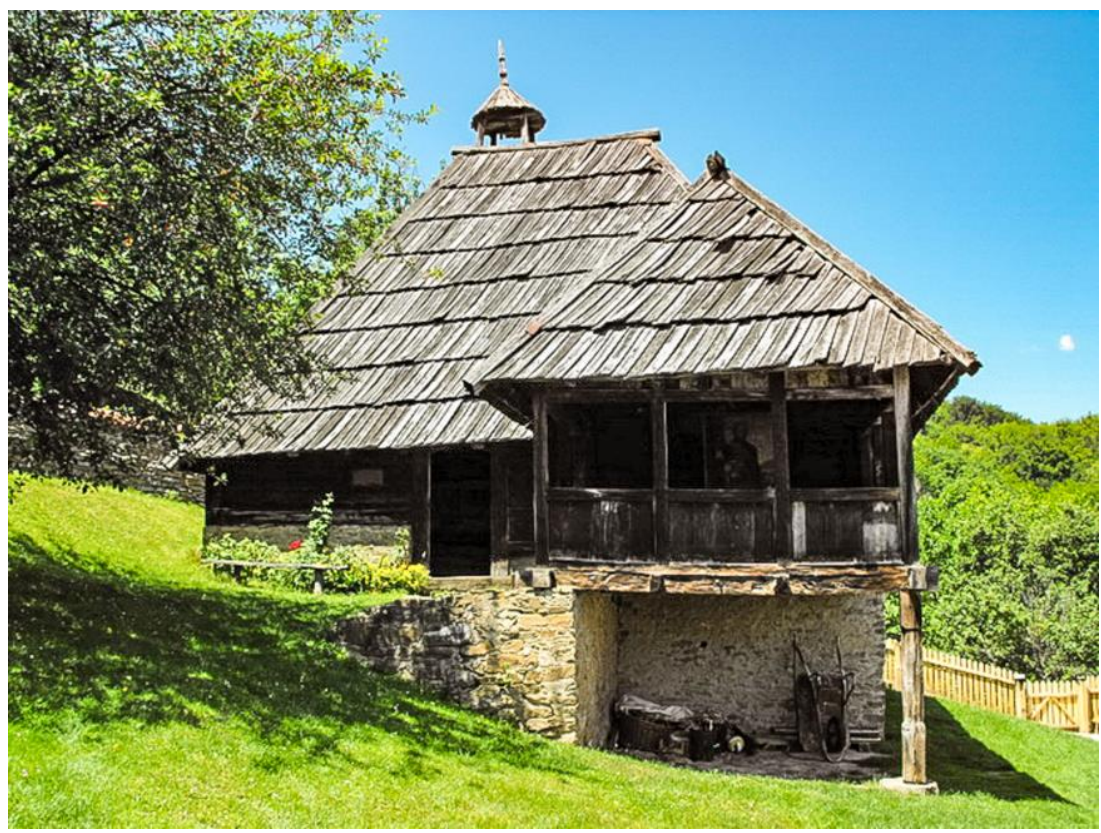

Fig. 3 Konak of Prince Milos in Gornja Crnuca in 2012, photo from a private collection.

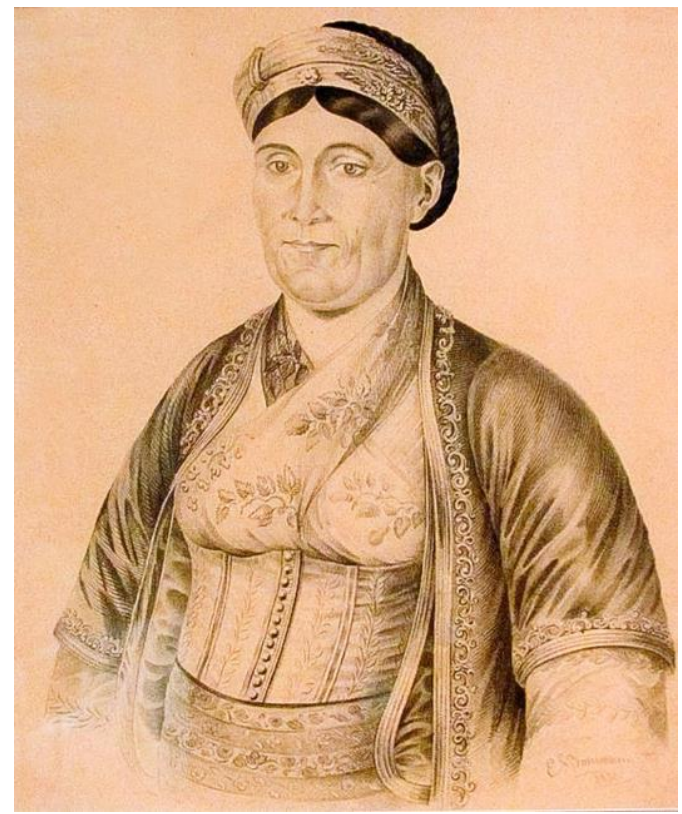

Fig. 4 Princess Ljubica Obrenovic, portrait from the collection of the National Museum in Belgrade 


\section{REFERENCES}

Borić, T. (2014). Dvorovi dinastija Obrenović i Karađorđević u Srbiji, Doctoral dissertation. Beograd: Univerzitet u Beogradu, Filozofski fakultet.

Borozan, I. (2006). Reprezentativna kultura i politička propaganda: spomenik knezu Milošu u Negotinu. Beograd: Filozofski fakultet, Katedra za istoriju umetnosti novog veka.

Deroko, A. (1940). Narodno neimarstvo II. Beograd: Institut za narodnu umetnost Beogradskog univerziteta.

Gavrilovć, M. (1909). Knez Miloš Obrenović II. Beograd: Zadužbina I. M. Kolarca

Kadijević, A. (2006). Arhitektura - okvir privatnog života u srpskim zemljama od početka 19. veka do Prvog svetskog rata, In: Stolić, A., Makuljević, N. (eds) Privatni život kod Srba u XIX veku. Beograd: Clio, 245258.

Kanic, F. (1986). Srbija zemlja i stanovništvo: od rimskog doba do kraja XIX veka. Beograd: Srpska književna zadruga.

Kojić, B (1958). Seoska arhitektura i rurizam: teorija i elementi. Beograd, Novi Sad: Građevinska knjiga, Zmaj

Kuljić, T. (2009). Oblici lične vlasti: sociološko istorijska studija o ideologiji i organizaciji uticajnih evropskih oblika lične vlasti od antike do savremenog doba. Beograd: Službeni glasnik.

Kunibert, B. S. (1901). Srpski ustanak i prva vladavina Miloša Obrenovića (1804-1850). Beograd: Zadužbina I. M. Kolarca

Ljušić, R. (1986). Kneževina Srbija 1830-1839. Beograd: Zavod za udžbenike i nastavna sredstva.

Marković, R. (1938). Pitanje prestonice u Srbiji kneza Miloša. Beograd: Zadužbina Luke Ćelovića-Trebinjca.

Milićević, M. Đ. (1876). Kneževina Srbija. Beograd: Državna štamparija.

Milićević, M. Đ. (1888). Pomenik znamenitih ljudi u srbskoga naroda novijega doba. Beograd: Srpska kraljevska štamparija.

Milićević, M. Đ. (1896). Kneževina Srbija. Beograd: Državna štamparija.

Milošević, G. (2006). Stanovanje u gradu i na selu, In: Fotić, A. (ed.) Privatni život u srpskim zemljama u osvit modernog doba. Beograd: Clio, 142-172.

Stolić, A. (2006). Rodni odnosi u „carstvu podeljenih sfera”, In: Stolić, A., Makuljević, N. (eds) Privatni život kod Srba u XIX veku. Beograd: Clio, 89-111.

Timotijević, M. (2006). Privatni prostori i mesta privatnosti, In: Stolić, A., Makuljević, N. (eds) Privatni život kod Srba u XIX veku,Beograd: Clio, 165-244.

Timotijević, M. (2012). Takovski ustanak - srpske Cveti: o javnom zajedničkom sećanju i zaboravljanju u simboličnoj politici zvanične reprezentativne kulture. Beograd: Istorijski muzej Srbije i Filozofski fakultet.

Vujović, B. (1986). Umetnost obnovljene Srbije: 1791-1848. Beograd: Prosveta, Republički zavod za zaštitu spomenika kulture.

Vuletić, A. (2006). Vlast muškarca, pokornost žena - između ideologije i prakse, In: Stolić, A., Makuljević, N. (eds) Privatni život kod Srba u XIX veku. Beograd: Clio, 112-132.

\section{KONAK U GORNJOJ CRNUĆI - DVOR KNEZA MILOŠA OBRENOVIĆA}

Proces zasnivanja $i$ oblikovanja prestonice pokazao se ključnim pitanjem reprezentativne kulture svakog perioda. Ovo je bilo od posebne važnosti kada je reč o devetnaestovekovnim društvima na teritoriji Balkana s obzirom na buđenje nacionalne svesti i stvaranje nacionalnih država na teritoriji koja je dugo bila pod osmanskom vlašću. Uprkos nespotojanju državnosti $i$ ekstremnim političkim okolnostima srpsko društvo pokazalo je zavidan stepen pozavanja evropskih fenomena kada je reč o stvaranju i odašiljanju vladarske slike kao važnog dela podsticanja svesti o nacionalnom identitetu. Srce Srbije pod ranom vladavinom Miloša Obrenovića bio je dvor u mestu Gornja Crnuća koje je uprkos svojoj strukturalnoj jednostavnosti bilo nepogrešivi odraz najvišeg državnog autoriteta.

Ključne reči: Gornja Crnuća, knez Miloš Obrenović, dvor, dinastički topos, vladar, prestonica 